\title{
RESENHA
}

\section{RELAÇÕES ÉTNICO-RACIAIS NA ESCOLA: O PAPEL DAS LINGUAGENS}

\author{
Lícia Maria de Lima Barbosa (UNEB)
}

\section{Referência da obra resenhada:}

LIMA, Maria Nazaré Mota de ${ }^{1}$. Relações Étnico-Raciais na Escola: O papel das linguagens. Salvador: EDUNEB, 2015. 134 p.

Numa nação composta por negros/negras, indígenas, discutir as relações étnico-raciais que constituíram esse país poderia ser algo fácil, mas a realidade brasileira nos mostra como é algo complexo e necessário na luta contra o racismo, na consolidação da cidadania, na construção da igualdade social e racial. A escola como um local privilegiado de transmissão de conhecimentos torna-se estratégica para transformar a sociedade. É neste cenário que festejamos a obra de Lima, uma das autoras de referência na discussão das relações étnico-raciais na educação, a partir do uso das linguagens.

A obra discute essa problemática, mostrando como questões relacionadas às identidades e poder estão relacionadas ao processo formativo e associa ao uso das linguagens no espaço escolar e na sala de aula. As reflexões da autora são fruto das suas vivências de Formação de Professoras/es em História e Cultura Afro-brasileira e Africana no CEAFRO Educação para a Igualdade Racial e de Gênero, um programa vinculado ao Centro de Estudos Afro-Orientais da Universidade Federal da Bahia (CEAOUFBA). São ideias gestadas também a partir da sua atuação no PósCrítica/UNEB - Programa de Pós-Graduação em Crítica Cultural, da

\footnotetext{
1 Maria Nazaré Mota de Lima - Doutora em Letras e Linguistíca e Mestre em Educação pela Universidade Federal da Bahia(UFBA). Licenciada em Letras Vernaculas (UFBA). Professora Adjunta da Universidade do Estado da Bahia(UNEB). Líder do Grupo de Pesquisa Iraci Gama do Programa de PósGraduação em Crítica Cultural (Pós-Crítica).
} 
Universidade do Estado da Bahia e sinalizam abordagens a serem feitas por professoras/es junto a estudantes da educação básica e superior, visando desmobilizar desigualdades raciais e promover direitos sociais no nosso pais.

Será que a leitura crítica do currículo escolar é suficiente para garantir uma igualdade de tratamento das diferentes pessoas presentes na escola? A demanda por justiça social empreendida pelos movimentos sociais, especialmente movimentos negros, indígenas, de mulheres, tem encontrado ressonância nas políticas de formação de professoras/es? É possível formar professoras/es que saibam lidar pedagogicamente com as diversidades? Reflexões sobre estas questões encontramos nesse livro em que a autora dialoga com memórias do trabalho desenvolvido por ela e outras companheiras no CEAFRO, assim como com autores/as diversos cujas ideias convergem para o que se defendia no programa.

Dentre outras questões discutidas na obra, Lima chama atenção para o fato de que a escola, enquanto espaço de disseminação de culturas, difunde valores e ideias que inferiorizam e deslegitimam povos negros e indígenas e, neste sentido, “[...] precisa ser criticada de modo a preparar sujeitos ativos, críticos, solidários, democráticos, no intuito de transformarem a sociedade nesta mesma direção" (p.23).

Resulta também o livro da tese de doutorado em Letras e Linguística, defendida pela autora na UFBA, um estudo que, ancorado na Etnometodologia, na Multirreferencialidade, faz jus a essa perspectiva, ao articular discussões da Linguística Aplicada Indisciplinar, Análise Crítica do Discurso, Estudos Culturais e Educação Antirracismo. O livro é estruturado em três eixos temáticos, versando: 1) sobre caminhos, descaminhos e enfrentamentos, nos modos de fazer educação das relações étnico-raciais; 2) sobre a escola enquanto território povoado de distintas identidades que podem ali se manifestar e se empoderar; 3 ) sobre discursos raciais na escola e a formação docente e discente para superação do racismo.

O tema do Racismo Institucional ganha relevância nas análises da autora, quando indica que o racismo na educação é de responsabilidade direta e indireta do Estado brasileiro - por promover exclusões e desigualdades raciais relativas ao direito à educação no país - e não resultado das ações de 
RESENHA

RELAÇŌES ÉTNICO-RACIAIS NA ESCOLA: 0 PAPEL DAS LINGUAGENS

uma ou outra professora. Neste sentido, ela demonstra que as políticas nacionais de educação ainda precisam avançar no que tange ao que é previsto nas leis 10639-03 e 11.645-08.

Quanto ao tema das identidades, é pensado em toda a obra, nas suas relações com as culturas. Conceitos como hibridismo, interseccionalidade, diáspora, dupla consciência, colonialidade do poder são trazidos para a discussão, de modo a explicar a relação entre dimensões étnico-raciais, currículo e poder, contribuindo para ensejar práticas educativas desconstrutoras do racismo e favoráveis à promoção da igualdade étnicoracial no cotidiano da escola e na sociedade.

A partir da análise de narrativas de formadoras e de professoras em formação, pontua que é preciso se expor, falar de si, de sua identidade étnicoracial, para conhecer o conteúdo de História e Cultura Afro-brasileira e Africana, evidenciando que esse processo se desenvolve como possibilidade de empoderamento de vozes subalternizadas em diferentes contextos.

É nesta perspectiva que ela conclui que a formação desenvolvida pelo CEAFRO, "bebendo" nas fontes de experiências e formulações emanadas dos movimentos negros e de mulheres negras, traz uma postura contrária à hierarquização e distanciamento, comumente verificados nas propostas de Secretarias e/ou Universidades. Daí que ensinar a lidar com o racismo na escola implica ensinar a lidar com o racismo em si própria/o e, a partir daí, apresentar conteúdos, métodos, técnicas de abordagem das questões étnicoraciais no currículo. Apesar das críticas contundentes ao Estado, à Escola, à Universidade, a autora defende que é possível conjugar esforços, articular alianças entre esses setores e os movimentos negros, a fim de corrigir a história de exclusão e desigualdades cometidas contra os negros, tendo as professoras à frente do processo e contribuindo para fazer justiça a esse segmento da população que construiu e constrói o país com seu trabalho cotidiano. Conforme assevera, "A formação de professores/as precisa contemplar seja a dimensão pessoal, seja a dimensão profissional dos educadores/as, seja a dimensão de políticas públicas a serem implementadas pelo Estado". (p.125) 
As análises de Lima nos mostram, enfim, como fronteiras étnicas, raciais e de gênero são produzidas no currículo escolar, nas práticas pedagógicas em sala de aula, entre as diferentes pessoas e grupos sociais que ali interagem e estão representados. Revelam também as conexões entre linguagem e poder, enquanto instâncias de produção de desigualdades. Ao mesmo tempo, as análises demonstram as peculiaridades e potência da formação de professoras/es e das linguagens na tarefa da reversão do racismo e ressignificação da cultura afro-brasileira e africana na escola, nas salas de aula, na sociedade.

Recebido em 1 de dezembro de 2016.

Aceito em 23 de dezembro de 2016. 